\title{
"Rehabilitating" Pilgrimage in Scotland: Heritage, Protestant Pilgrimage, and Caledonian Caminos
}

\author{
Marion Bowman \\ Religious Studies, The Open University, Milton Keynes, United Kingdom \\ marion.bowman@open.ac.uk
}

\begin{abstract}
Caminoization and the heritagization of religion are significant factors in the development of "new" pilgrimage in Scotland this century, helping to produce pragmatic and distinctive reworkings of pilgrimage in what was, traditionally, a predominantly Protestant milieu. Here I review the pre- and post-Reformation context of Scottish pilgrimage, outline significant influences and agents in "new" Scottish pilgrimage ideas and praxis (including the Scottish Pilgrim Routes Forum), and give a detailed account of the development of the Fife Pilgrim Way (officially launched in July 2019) as an example par excellence of how pilgrimage currently is being operationalized and reframed, influenced by both Caminoization and heritagization. This analysis shows that Scotland's contemporary "rehabilitation" of pilgrimage is driven by multiple agents and agendas (religious, civic, economic, and societal), and that its roots lie inter alia in Scotland's complex identity politics, Celticism, sectarianism, pro-European sentiments, and a pragmatic reassessment of and reengagement with Scotland's fragmented pilgrimage past.
\end{abstract}

\section{Keywords}

Scotland - pilgrimage - Caminoization - heritagization - Church of Scotland Scottish Pilgrim Routes Forum

In this article I examine current trends in the Caminoization and the heritagization of religion in relation to the growth of "new" pilgrimage in Scotland. The Camino de Santiago de Compostela, designated a Cultural Route of the Council of Europe in 1987, has come to epitomize the trend toward "heritagization" 
of religion, whereby material culture, places, and praxis from the past are (re)presented as meaningful in the present (Bowman and Sepp 2019; Bowman, Johannsen, and Ohrvik 2020). The heritagization of the Camino has made it attractive for an extremely broad demographic (Frey 1998; Margry 2008; Gemzöe 2012; Castro Fernández 2016), and this reframing of pilgrimage, with the emphasis no longer on the shrine at journey's end but on the journey itself, has prompted numerous (re)developments of pilgrimage paths in Northern Europe, as we see in this special issue of Numen.

Here I concentrate on the ways in which "new" pilgrimage is being perceived and (re)presented in relation to Scottish Christianity. While it would be overstating the case to talk of a Protestant de-Reformation, pilgrimage, which was questioned, rejected, and widely condemned in the 16th century and beyond, is being reframed and to varying degrees reintegrated into a rapidly changing Scottish social and spiritual milieu. Reframing pilgrimage as heritage means it can be used "to construct, reconstruct and negotiate a range of identities and social and cultural values and meanings in the present" (Smith 2006: 3). Inviting people to reassess, become heirs of and participants in, an activity once widely discredited represents a significant shift as to how a conflicted, disrupted religious past might be renegotiated. The Church of Scotland and various Protestant churches, along with other ecumenically inclined Christians, are finding in pilgrimage new ways to engage with each other, the past (including Scotland's sectarian history), the environment, and broader society, and to reinforce Scotland's self-identity as a culturally distinct nation with strong European affinities. However, the pilgrimage paths that are proliferating and the apparent popularity of new pilgrimage do not represent a straightforward revival of pilgrimage; they are the product of a distinctively Scottish, pragmatic, rather Protestant "rehabilitation" of it.

\section{Historical Background: a Land of Lost Content}

The Reformation in Scotland ruptured a pilgrimage tradition and infrastructure that had existed for centuries. Scotland's early Christian history is connected with St. Ninian, a Briton who studied in Rome and is credited with establishing Scotland's first church at Whithorn in the 4th century, and in the $5^{\text {th }}-7$ th centuries with numerous Celtic saints who, along with the places associated with them, subsequently became foci of veneration and pilgrimage. While St. Columba was enormously significant and Iona enjoyed pre-eminence and royal connections in earlier centuries, developments in Scotland's highly contested internal identity politics led the focus of pilgrimage to shift to the 
"pilgrim kingdom" of Fife. As Tom Turpie comments, "The economy, communication networks, landscape and religious and cultural life of Fife, perhaps more than any other region of medieval Scotland, was shaped by the presence of pilgrims and the veneration of saints" (2016:4). ${ }^{1}$

Scotland's pre-eminent medieval shrine was St. Andrews in Fife. According to one popular legend, the relics of St. Andrew were brought from Patras to Kinrymont (the Pictish site which later became St. Andrews) by St. Regulus (also known as St. Rule) in the 4th century in response to a vision. Bishop Acca of Hexham $(c .660-740 / 2)$ is sometimes associated with the arrival of the relics in Scotland in the 8th century (Yeoman 1999; Bradley 2019). The trope of Scotland as a country hosting the relics and under the special protection and patronage of St. Andrew was promoted vigorously "to counter the claims of overlordship, secular and religious, from England” (Yeoman 1999: 55). St. Andrew's relics were moved from St. Rule's Church to St. Andrews Cathedral, under construction from the twelfth to the fourteenth centuries, which was consecrated in 1318 in the presence of Robert the Bruce, King Robert I of Scotland (1274-1329), four years after his victory over the English at the Battle of Bannockburn. By the late Middle Ages, St. Andrews Cathedral was the largest building in medieval Scotland. St. Andrew, as brother of St. Peter and a martyred apostle, was a high-status saint whose shrine, in theory at least, could rival that of Santiago de Compostela - though it never attracted European pilgrims on anything like the same scale.

In the 11th century, Queen — subsequently Saint — Margaret (c.1045-1093) is credited with funding free ferries for pilgrims crossing the River Forth between the settlements of South Queensferry and North Queensferry on their route to St. Andrews, and endowing pilgrim hostels on each side of the Forth. Margaret was buried at the royal palace church at Dunfermline, also in Fife, with many miracles popularly attributed to her after her death. Following her canonization, in 1250 St. Margaret's remains were placed in a magnificent shrine at Dunfermline Abbey, already a prestigious location as the burial place of numerous Scottish royal figures, and it in turn became a significant focus for pilgrimage and devotion in its own right, as well as a popular detour for pilgrims journeying to St. Andrews (Bradley 2019: 74-90).

The Reformation in what is now the United Kingdom happened at different times and with different outcomes in its constituent countries. While in England, the distinctive Anglican Church (broadly Lutheran in its theology)

1 Medieval Historian Tom Turpie (2016) produced a detailed report in relation to the development of the Fife Pilgrim Way that helpfully brings together significant historical references to pilgrimage and the cult of the saints in Fife. 
emerged as the official established church, retaining a hierarchical structure of archbishops and bishops with the monarch at its head, the Church of Scotland was Presbyterian, not Episcopalian, with authority vested in the General Assembly rather than the monarch. The Scottish Parliament declared Scotland Protestant in 1560 in defiance of the Catholic Queen Mary. The establishment and long-term influence of the Calvinist-inspired, Presbyterian Church of Scotland as the national Church ensured that pilgrimage was theologically discredited, and physically dismantled at an institutional level; it was officially banned by Act of Parliament in 1581. Dunfermline Abbey, for example, is now a building of two halves; the large, empty nave is administered by Historic Environment Scotland as an historic site, while the purpose-built early 19th-century Dunfermline Abbey Church (Church of Scotland), erected on the "footprint" of the previous Abbey choir area, houses the remains of Robert the Bruce, although the remnant base of St. Margaret's shrine stands outside the church building (Figure 1). The once magnificent St. Andrews Cathedral fell into total ruin. Thus, in common with other Northern European Protestant countries, although many older churches physically remained in

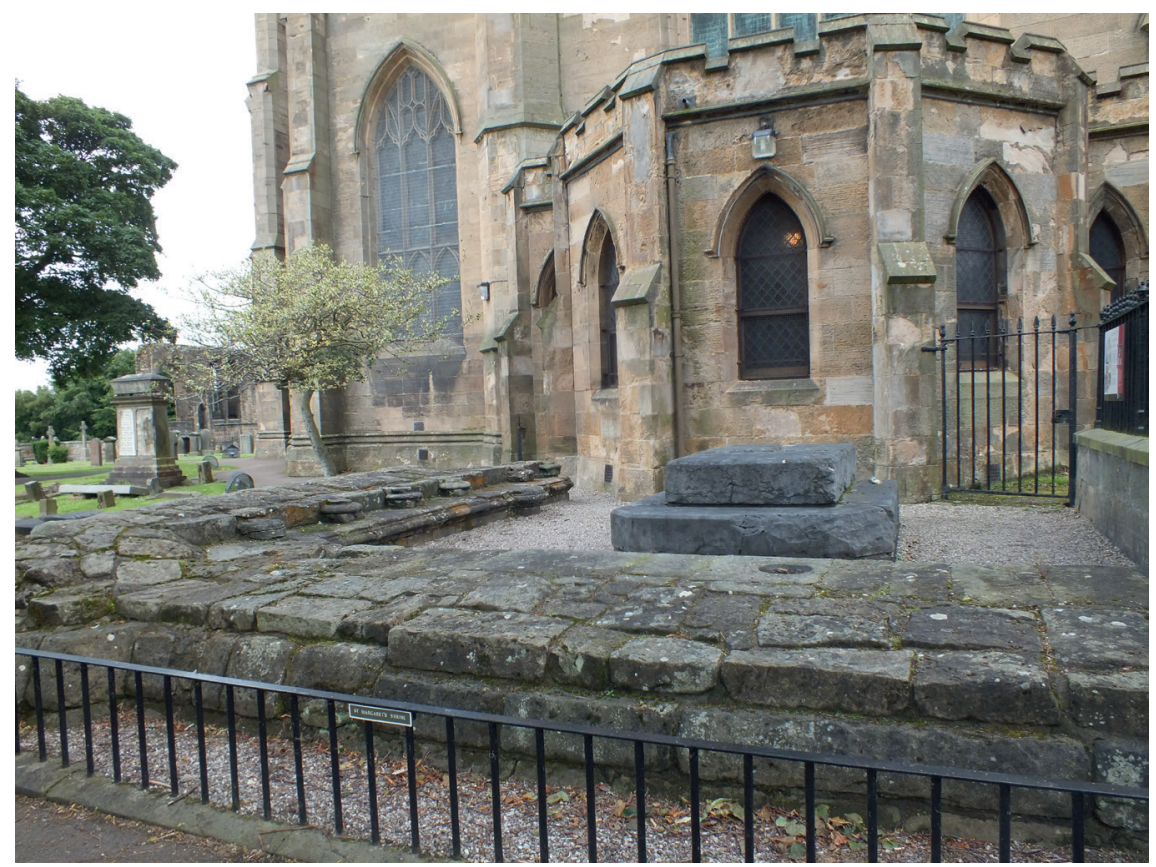

FIGURE 1 Remains of base of shrine of St. Margaret, now outside Dunfermline Abbey Church.

PHOTOGRAPH: MARION BOWMAN 
use as parish churches, for the most part the former foci of pilgrimage, the traditions and material culture of pilgrims, and the infrastructure of hospitality to pilgrims were gone.

In 21st century Scotland, however, a range of people and agencies with a variety of agendas are now seeking to reframe Scotland's lost pilgrimage heritage, to represent and re-present pilgrimage nationally not as a discredited, largely abandoned religious practice but as a multiagency, multivalent means of creating spiritual and practical benefit in the contemporary milieu. While people talk of the "revival" of pilgrimage, it is not about the reintroduction of traditional Roman Catholic praxis. Pilgrimage is being restored and sites and landscapes are being re-storied in ways that are significantly different from the pre-Reformation model, involving heritagization of the past and the rehabilitation of pilgrimage for the present and future. Some of the strands, trends, and circumstances leading to the contemporary location of pilgrimage in Scotland are now explored.

In order to understand some aspects of new Scottish pilgrimage, it is necessary to comment briefly on contemporary understandings of Celtic Christianity that have been instrumental in promoting interest in Celtic saints and the legends, sites, stories, and praxis — including pilgrimage — associated with them in post-Reformation Scotland and elsewhere.

Celtic scholar Joep Leerssen describes "Celticism" as "the history of what people wanted that term [Celtic] to mean" (Leerssen 1996: 3), a trait obvious in relation to modern ideas of Celtic Christianity. In the late 18th, 19th, and 2oth centuries there were Celtic revivals, each contributing to the notion of the "spiritual Celt," providing contemporary inspiration for a range of Christians, pagans, Druids, nonaligned spiritual seekers, and others (Bowman 1993, 2000; Maddrell and Scriven 2016; Butler 2020). Ian Bradley notes that even at the time of the Reformation, there was "interest in and appropriation of the Celtic Church as a prototype of sturdy independent British Protestantism" (1999: viii). ${ }^{2}$

Celtic Christianity has come to be seen as more "spiritual," more intuitive, more embodied, more egalitarian, and more in tune with nature than other brands of Christianity (qualities felt by many to be missing from the

2 A Church of Scotland Elder told me that if the Celtic church had been allowed to continue, there would have been "no need for the Reformation." 
institutionalized Church) allowing "those Christians who lived in the sixth and seventh centuries, about whose faith and work we know next to nothing first hand, to become paragons of a pure and primitive faith" (Bradley 1999: ix). Thus we see the widespread use of so-called "ancient Celtic" prayers and blessings from Scottish and Irish sources (some in fact of 19th and 2oth century origin, simply written in the style of English translations from Gaelic), not only in the British Isles and Ireland but elsewhere in northern Europe (e.g., Sepp and Remmel 2020: 6oo, 603), regarded as a sort of lingua franca of "authentic" Christianity. ${ }^{3}$

The perceived desirability of "reconnecting" with Celtic saints, sites, and praxis has led at various points to the growth of renewed interest in significant Celtic Christian places and the people associated with them (e.g., Lindisfarne, St. Aidan, and St. Cuthbert in England, ${ }^{4}$ Iona and St. Columba in Scotland, Kildare and St. Bride in Ireland). In Scotland in the 2oth century the island of Iona became increasingly important for a great variety of Christians (and diverse others ${ }^{5}$ ) as a place of spiritual refreshment and healing, being remote and beautiful, very much "on the edge" for most people traveling there, thus conforming to and confirming a particular image of "otherworldly" Celtic Christianity. ${ }^{6}$ The ecumenical Iona Community, founded in the 1930 by George MacLeod (then a Church of Scotland parish minister in Govan, in the industrial central belt of Scotland), was very much rooted in social concern; rebuilding the ruined Iona Abbey provided a means of engaging some of the unemployed affected by the 193os economic depression. However, MacLeod made creative use of his version and understandings of Celticity (see Power 2006: 41-45) in the development of distinctive worship and praxis, and the Iona Community for many became and remains an icon of Celtic Christianity. ${ }^{7}$ Significant in tracing the trajectory of some new pilgrimage activity, Celtic

3 In February 2020 the twelfth annual Pilger-Messe symposium, at which 40 pilgrimage and pilgrim route groups from across Germany and Scandinavia exhibited, was held in Hamburg. Professor Ian Bradley attended, having been invited to speak on Celtic Christianity to a group of Pilger-Messe participants.

4 The Northumbrian St. Cuthbert tends to be described as both a Celtic and an Anglo-Saxon saint. His career started in the Celtic church but he was active after the Synod of Whitby in 664, which established Roman rather than Celtic usages in the Northumbrian church.

5 See, for example, Power 2006; Bhattacharjee 2018.

6 Selja, the island off the west coast of Norway connected with St. Sunniva (Mikaelsson and Selberg 2020) promoted itself as "Norway's Iona" in the early 200os on account of St. Sunniva's legendary "Celtic" origins.

7 Power observes, however, that while "the Iona Community is expected by many to be a leading proponent of Celtic spirituality ... it has at best an ambiguous relationship with it" (2006: 36). 
Christianity became a vehicle whereby various denominationally aligned Christians began to act atypically and experimentally (Meek 200o). In the case of many Protestants, this was by going on pilgrimage to places such as Iona and other locations associated with Celtic saints.

The fact that many Scottish Celtic saints were wanderers, with reputations for making long missionary, preaching, and pastoral journeys, leaving numerous wells and other sites named for them, affords contemporary opportunities for connecting with them through walking trails, spiritually inspired or inspiring journeys, and pilgrim paths. Commenting on the growing interest in Celtic pilgrimage, Maddrell and Scriven suggest two factors for the increased openness to pilgrimage of some Protestant clergy and congregations:

Firstly ... greater theological openness and ecumenical engagement, which have increased receptivity to new practices and expressions of faith. Secondly, pilgrimage can be seen as part of changing spatial practices, including "taking the church out of doors" in the face of declining regular attendance at church.

MADDRELL AND SCRIVEN 2016: 3O2-3O3

While these are undoubtedly significant influences, there is a further agenda in the case of Scotland. Sectarianism in the form of Catholic-Protestant strife (now frequently secular or cultural sectarianism), has been and remains an ugly aspect of Scottish life. Focusing on the common heritage of the early Scottish church and Scotland's Celtic saints, their itineraries and places associated with them can provide both a narrative and a model of "pure," presectarian, pre-Protestant/Catholic conflicted Scottish Christianity. It is this past that is frequently highlighted in new pilgrimage initiatives, which tend to aspire to ecumenism, as the Church of Scotland, the Scottish Episcopal Church (Anglican in doctrine and practice, but independent from the Church of England), the Roman Catholic Church, and indeed Scotland's Orthodox churches, can all claim connection with such saints and places.

\section{Caminoization and the Transition from Walking to Pilgrimage in Scotland}

The growth of pilgrimage-inspired walking in Northern Europe, like the huge general increase in recent decades of long-distance walking routes, has tapped into and been part of a growing appetite for recreational walking and an element of physical challenge. Long-distance recreational walking has long been 
popular in Scotland, a trend that started with romantic tourism in the 18th century. It was boosted as a working-class phenomenon during the depression of the 1930 shen many from Scotland's central industrial belt would walk into the countryside as recreation and release during economically desperate times, and remains an activity enjoyed by a broad range of people. ${ }^{8}$ In addition to innumerable footpaths and informal walking opportunities, there are currently 29 managed, waymarked routes flagged as "Scotland's Great Trails," ranging in length from 24 to 210 miles ( $40-340 \mathrm{~km}$ ). These trails offer opportunities to "explore Scotland's scenery and wildlife, and experience our amazing history and culture" (Scotland's Great Trails 2020). They also have significant socioeconomic aspects, with the West Highland Way estimated to generate " $£_{5}$ million a year in economic spin-off" (ACTS 2018: 45). While many people undertake such trails in their entirety, the great majority of walkers tend to tackle sections of trails such as the West Highland Way or the Fife Coastal Path as day or weekend walks. ${ }^{9}$

Among the Great Trails is listed St. Cuthbert's Way, ${ }^{10}$ perceptions and use of which have changed since its inauguration in 1996, reflecting both the growing appetite for pilgrimage and creeping Caminoization. As its official website proclaims:

Bridging the national border between Scotland and England, this inspiring $100 \mathrm{~km}$ (62.5 miles) cross-border route links Melrose in the Scottish Borders, where St. Cuthbert started his religious life in $650 \mathrm{AD}$, with Holy Island off the Northumberland Coast, his eventual resting place and his original pilgrimage shrine. Although inspired by St. Cuthbert, this is far more than a pilgrimage route.

ST. CUTHBERT'S WAY, n.d.

Even though St. Cuthbert is used as the link between places, and the waymarking logo is "based loosely on St. Cuthbert's pectoral cross" (Shaw 2016: xii),

8 However, there is an under-representation of people with a disability, Muslims, residents in Scotland's most deprived areas, and black and other non-white minority ethnic groups participating in leisure walking (see Colley and Irvine 2018: 2).

9 Annual visit estimates for the West Highland Way is 120,ooo visits, including 36 ,ooo endto-end users; for the Fife Coastal path 500,ooo visits, including 35,000 end-to-end users (Scottish Natural Heritage 2018).

10 Although it is now a transnational trail, in St. Cuthbert's time both Melrose and Lindisfarne lay within the former Kingdom of Northumbria. For a detailed account of the history of St. Cuthbert and the area traversed by the trail, see Cusack 2013 . 
initially this trail was neither envisaged nor marketed primarily as a pilgrim way, nor does it follow an actual ancient pilgrim route.

The idea for St. Cuthbert's Way originated with the Till Valley Tourism Initiative on the English side and was progressed with the cooperation and enthusiasm of the Walking Development Officer for the Scottish Borders. Long-term unemployed were involved in the path's construction on the Scottish side, and as the 2oth anniversary edition of the Official Trail Guide notes, one reason for creating the route was "to provide economic benefit for the communities through which it passes and others close to the route. There is no doubt that this has happened" (Shaw 2016: xi).

Increasingly popular among people aware of and inspired by the Camino (through walking the Camino itself or other spin off pilgrim paths), however, the number of self-styled pilgrims (as opposed to walkers) has increased significantly through the 20oos, according to one local walking services provider, John Henderson of Melrose-based Walking Support." In Henderson's experience, St. Cuthbert's Way has proved particularly popular with pilgrim groups from Scandinavia, especially Norway. In response to popular demand from his pilgrim/Camino-influenced clients, Henderson created a certificate of completion of the St. Cuthbert's Way for those who wished to have one, and maintains a website dedicated to Pilgrimage Ways and Tours (see Walking Support 2010). Developed in 1996 primarily as a long-distance walking trail, St. Cuthbert's Way has become increasingly seen through the lens of Caminoized pilgrimage, reflecting the widespread expansion of pilgrimage walking in Northern Europe. It thus epitomizes an interesting transition in expectations and demand between walkers and self-styled pilgrims. However, subsequently new pilgrimage paths, self-consciously drawing on both heritagization and Caminoization, have been deliberately developed in Scotland, for Scotland, in response to a variety of religious and social factors, and involving a range of agencies and agendas.

\section{4 \\ A New Vision: the Scottish Pilgrim Routes Forum (SPRF)}

The development of dedicated pilgrimage-oriented walking paths with appropriate infrastructure requires significant planning, vision, coordination, and investment. The promotion and creation of many of the newest Scottish pilgrim paths are largely locally inspired, bottom-up initiatives. A leading role in bringing these about has been played by the Scottish Pilgrim Routes Forum

11 Personal communication 2018. 
(SPRF), a Scottish charitable organization founded in 2012 and now comprising a network of over 90 organizations and individuals "committed to developing off-road pilgrim walking routes across Scotland” (Scottish Pilgrim Routes Forum 2019a). A number of exploratory meetings were held from 2010 onwards involving the Scottish Churches Rural Group of ACTs (Action of Churches Together in Scotland), ${ }^{12}$ Scottish Parliamentarians, Scottish Natural Heritage, Visit Scotland, Scotland's Churches Trust, community enterprises, and individual pilgrimage enthusiasts to examine the potential development of faith tourism and pilgrimage walking routes (Scottish Pilgrim Routes Forum, n.d.). In 2011, the ACTS SCRG launched a public manifesto entitled "Pilgrim Routes across Scotland" in the Scottish Parliament. Almost simultaneously, the following Declaration of Intent was signed by Scotland's Church leaders and the Cabinet Secretary for Rural Affairs and Environment:

Rejoicing in the growth of interest in pilgrimage, in both the churches and wider society, we as church and civic leaders commit to support in principle the development of pilgrimage and of pilgrim routes as spiritual and community led activities important to Scotland.

Quoted in COOKE 2012

Referring to the establishment of SPRF, Nick Cooke, Secretary of the Forum, wrote:

Such is the scale of the current revival of public interest in pilgrimage travel, there is a real need to create a structure and process for coordinating the various new pilgrim route initiatives that are now emerging across Scotland ...

We are not seeking to impose a blueprint "master plan" to be rigidly followed, but rather provide a flexible and mutually supportive network to enable and encourage local partnerships of member bodies to learn from others. Critically, we want communities and individual churches of all denominations and sizes to be actively involved in a process of rural regeneration with important social, environmental and economic — not to mention spiritual - benefits. We only have to look to Europe, and

12 ACTS currently has nine member churches: Church of Scotland, Roman Catholic Church, Scottish Episcopal Church, Congregational Federation, Methodist Church, Religious Society of Friends (Quakers), Salvation Army, United Free Church, and United Reformed Church. 
Scandinavia in particular, to see inspiring examples of this in the many pilgrimage trails created over the last 20 years.

COOKE 2O12: 15

It is interesting to note the influence of Scandinavia here, underlining the extent to which pilgrimage developments elsewhere in formerly Protestant Northern Europe, as well as the Camino itself, have been influential in the Scottish context.

The Forum nomenclature was chosen to stress that this is a bottom-up organization, facilitating local initiatives for which there had to be sustainability and local buy-in, energies, and enthusiasm. Among those involved in the Forum are people who "found their feet" and developed an interest in "rediscovering Scotland's lost pilgrimage heritage" on the Camino and other pilgrim paths. ${ }^{13}$ As indicated by Cooke (2012), pragmatic drivers for the promotion and operation of new routes and sharing best practice among members include the desire to revive rural or postindustrial economies, to facilitate social, economic, and community regeneration and wellbeing, to increase environmental awareness and sustainability, and to find new purposes for church buildings and dwindling congregations. As the Forum could show, the proven economic benefits of long-distance walking routes and the regenerative effects of the Camino all indicate strongly that pilgrimage could have not only spiritual but also economic and social value. As Ian Reader has pointed out, financial dynamics "are not antithetical to pilgrimage ... but crucial in its successful functioning, development, appeal and nature" (2014: 14-15).

Furthermore, interest from the Scottish Government in SPRF is related not simply to rural regeneration and heritage tourism, but to the perceived value of the paths in its efforts to promote exercise and improve health in Scotland. The broad appeal and multipurpose benefits of contemporary pilgrimage are self-evident to the SPRF, which "represents a contemporary movement rooted in an ancient tradition, meeting a widely-felt need in today's society where anyone can benefit through pilgrimage whether they are religious or not" (SPRF 2O19a). SPRF has both been influenced by, and has itself influenced, new appreciations of pilgrimage in Scotland and has played an extremely significant role in promoting and coordinating the development of purpose made, dedicated pilgrim paths.

When cartographer David Langworth first produced a map for SPRF outlining the Forum's vision for pilgrim paths in Scotland it was largely aspirational, with only two paths, the already established Borders Abbeys Way and

13 Personal communications. 
St. Cuthbert's Way, marked as operational. The 2019 edition of the map (Figure 2) now records six operational pilgrim routes, the St. Magnus Way, Forth to Farne Way, Whithorn Way and Fife Pilgrim Way all having been added in the meantime, with seven more routes shown as being under development. The map reflects the previously identified interest in early Scottish saints in several of the new and planned routes, such as St. Conan's Way and the Whithorn Way.

Reflecting on the SPRF's influence and activities, Cooke comments:

When SPRF came into being in 2012, there was no blueprint for how many pilgrim walking routes could be created across Scotland, their location, or the timescale involved. Eight years later, we can now identify over 1,00o miles of walking routes connecting the historic shrines of the early Saints and other holy places across the country. This hugely encouraging progress has been made possible by local people and communities wanting to play their part in the revival of Scotland's rich pilgrimage heritage. This is what the Forum was established for. ${ }^{14}$

Over recent years SPRF has invested considerable time and research in establishing a new Scottish Pilgrim Way accreditation scheme, to be launched in 2020 and designed both to help people plan pilgrimage walks, so that they know what to expect when using different routes, and also to be aspirational, encouraging local volunteer steering groups to identify ways in which "their" route can be improved and for which information and support from SPRF can be sought. The ACтs Scottish Churches Rural Group report, Hope in the Rural Church, highlights one particular need, commenting that

There is an acute shortage of budget hostel-type accommodation on our Pilgrim Way routes but a surfeit of increasingly under-used church buildings ... If we thought about our many historic rural church buildings in Scotland more creatively, we could adapt empty churches to create a network of Christian "heritage spaces" adapted for use both for hospitality and worship - bringing local people and pilgrim together.

ACTS SCOTTISH CHURCHES RURAL GROUP 2O18: 45

The same report quotes the example of St. Aidan's Church in Morebattle in the Scottish Borders, where the 1866 church building, closed in the 196os and subsequently used as a bus depot and a hauler's yard, was bought in 2010 and adapted. Half the building operates as a "free" church, open for worship, and

14 Nick Cooke, Personal communication, April 2020. 


\section{PILGRIM ROUTES 2019}


FIGURE 2 Map of Pilgrim Routes 2019, produced by David Langworth for SPRF

\section{Mileages}

Existing Routes.

St Magnus Way - 55 miles

Fife Pilgrim Way - 64 miles

Whithorn Way - 149 miles

Forth to Farne Way - 72 miles

Borders Abbeys Way - 64 miles

St Cuthbert's Way - 62 miles

Routes under Development

(current estimates)

Northern Pilgrims Way - 95 miles

Deeside Way - 44 miles

Iona to Killin - 90 miles

Three Saints Way

(Killin to St Andrews) - 111 miles

St Conan's Way - 63 miles

Dalriada Way - 102 miles

Kentigern Way - 150 miles

\section{Routes under development}

(2) Deeside Way

(3) Iona to Killin

(3.) Three Saints Way

Con's (Damally tolona)

Scotland's Great Trails

Holy Island $\boldsymbol{T}$

\section{COPYRIGHT SPRF}


the other half as the St. Cuthbert's Coffee Stop providing catering for visitors and pilgrims on the St. Cuthbert's Way, under the aegis of the Scottish Episcopal Church.

The new Scottish Pilgrim Way accreditation scheme, envisaged as being "in the long-term interests of path developers and users, churches, local communities and rural businesses alike" will, claims Cooke, underline "Scotland's unique place in the remarkable European revival of Christian pilgrimage and faith tourism in the early 21 st century."15 As one SPRF trustee was keen to stress, the new pilgrimage paths are not "just" Caledonian Caminos; they are responses to specifically Scottish religious and sociocultural issues, including Scotland's strong sense of European identity, and (in some quarters at least) they are physical manifestations of seismic shifts in Scottish and particularly Protestant attitudes to pilgrimage. The symbiotic relationship between the activities of the SPRF and new pilgrimage developments, and the changing religious backdrop in Scotland are now considered.

\section{5}

\section{New Pilgrimage in a Changing Religious Climate}

The idea of the pilgrim in the Church of Scotland, as in other Protestant traditions, has been informed by works such as the 17th-century Pilgrim's Progress by John Bunyan, as the metaphysical faith journey of the individual through life. However, various circumstances, trends and initiatives have colored the development of new attitudes to and reframings of pilgrimage in hitherto unexpected places.

Institutional Christianity in Scotland declined significantly from the latter part of the 2oth century, with the 2016 Church Census indicating that only 7.2 percent of the Scottish population regularly attended church, down from 17 percent in 1984 (Brierley 2017). By the early 200os, there were more people self-identifying as being of no religion than as Church of Scotland members. As the national church, the Church of Scotland has for some time been aware of its decreasing religious and numerical influence in contemporary Scotland, with traditional measures of church affiliation, community significance, and national influence seemingly in decline. In response, at institutional, parish, and individual levels, there have been significant initiatives to renegotiate the Church's place in Scottish life. A Church of Scotland report entitled A Church without Walls reflected that "The cultural appropriateness of much church life is sadly out of tune with the times" (General Assembly of the Church of

15 Nick Cooke, personal communication, April 2020. 
Scotland 2001: 13), recognizing the need and making copious suggestions for connecting both with other Christian churches and the people beyond the pews. Various experiments and initiatives have been developed under the leadership of individuals, ministers, or congregation members. A number of Church of Scotland congregations have become involved in Eco-Congregation Scotland, for example, "a movement of Scottish church congregations, of all denominations and none, committed to addressing environmental issues through their life and mission" (Eco-Congregation Scotland, n.d.).

Increasingly, pilgrimage has been seen as particularly helpful in terms of community-building, nourishing church congregations, and being attractive to those not interested in affiliative religion. As previously noted, Scotland's Celtic saints and places associated with them have been seen as useful in providing a vision of nonsectarian Scottish Christianity. At Luss, a small village on Loch Lomond-side, an experimental pilgrimage center was created by the then minister, Dane Sherrard, and the congregation of the Church of Scotland parish church dedicated to the Celtic St. Kessog. In 2010, a pilgrimage trail was created on the church's glebe land to celebrate the 1,50oth anniversary of St. Kessog's coming to Luss. Drawing on European contacts and funding, youth groups from Scotland, Finland, the Czech Republic, and Italy worked on the trail as volunteers, bringing together a mixture of nationalities and religious affiliations. Signboards located along the trail told the story of St. Kessog and stressed Luss's heritage as a Celtic Christian site, along with biblical and other inspirational quotations. Significantly in relation to its ecumenical intent, Stations of the Cross, a distinctive feature of Catholic material culture, were positioned around the site. Representing Scotland, Luss became one of the founding members of the Green Pilgrimage Network, launched at Assisi in autumn 2011 (ARC, n.d.). This site-focused pilgrimage initiative has not stood the test of time and the pilgrimage path is no longer maintained; however, other more journey-focused pilgrimage initiatives are being pursued in relation to Luss.

Underlining the sense of Europeanness felt and expressed by many Scottish civic and religious bodies, ${ }^{16}$ the Church of Scotland's World Mission Council report Together We Walk highlighted the church's "historic roots in wider European Christianity" (Church of Scotland 2014a: 6), suggesting among other activities that congregations might like to organize "A European themed Pilgrimage" around their church buildings, "related to our history and heritage with our partner churches in Europe" (Church of Scotland 2014b: 1). Pilgrimage

16 Scotland has been and remains enthusiastically "European”; unlike England, in the 2016 European Referendum Scotland registered a 62 percent "Remain" vote. 
was described in this context as "journeys put in God's hands ... The idea of journeying together, walking with God and finding God in our conversations and reflections as we walk together is important" (1).

While Lutherans in Northern Europe and Anglicans in England have been intimately involved both with walking the Camino and the development of new pilgrimage in Northern Europe, in many cases the theological ambiguities and ramifications of this have not been clearly articulated (Mikaelsson 2019; Bowman and Sepp 2019). In a remarkable reappraisal of the Scottish Protestant tradition, however, a Deliverance (report) on pilgrimage was presented to the General Assembly of the Church of Scotland in 2017. This was spearheaded by Richard Frazer, Minister of Greyfriars Church, Edinburgh, convenor of the Church of Scotland's Church and Society Council and a selfidentified "passionate pilgrim" - he has published a book on his experience on the Camino de Santiago (Frazer 2019). The premise of the Deliverance was bold and unequivocal: "This report seeks to rehabilitate pilgrimage as a genuine and meaningful spiritual pathway, officially to reverse a policy that has suppressed and discouraged pilgrimage since the Reformation" (General Assembly of the Church of Scotland 2017: § 9.3.6). The Deliverance mentioned the influential role of the SPRF, and the opportunities pilgrimage could give for meeting people where they are - the subtext (as reflected in A Church without Walls) being that they are not in the Church. The stress on physical effort in making the journey resonates with Caminoization:

A pilgrimage route does not have to be long distance or require foreign travel even though both are valid. It can be local, within a parish, and a pilgrim journey may just take a few hours rather than days or weeks. But we do believe it is best undertaken on foot or otherwise, under our own efforts if possible, rather than by powered transport. A journey by car or plane to a holy site may offer spiritual benefits but we are primarily concerned here to promote pilgrimage which involves some physical commitment by the pilgrim.

GENERAL ASSEMBLY OF THE CHURCH OF SCOTLAND 2O17: $\$ 9.4 .4$

The importance of the "storied" landscape, the environment, and the embodied experience of place is recognized, as revealed in this passage:

For those who embark on a pilgrimage, the landscape is not a mere backdrop to the journey, it frequently carries the marks of a narrative that tells the story of faith down the centuries, in living places of worship and service and in long abandoned sacred sites ... In addition, the landscape 
can become an active participant in the spiritual journey connecting the pilgrim to the environment, testing us and reminding us of our dependence on a thriving and living planet.

GENERAL ASSEMBLY OF THE CHURCH OF SCOTLAND 2O17: $\$ 9 \cdot 3 \cdot 7$

Finally, the importance for pilgrimage in relation to churches and congregations was stressed:

Pilgrimage offers new opportunities for churches and congregations on pilgrim routes to serve others, for example by providing shelter and hospitality. Many of the medieval refugios or pilgrim hostels on the Camino were founded and managed by monasteries or other religious foundations, and many remain so today. We encourage churches in Scotland to follow this example and to look at the opportunity to offer hospitality or perhaps help support community businesses to provide food and shelter for pilgrims in Scotland. This is also an opportunity for ecumenical development supported by ACTS, in partnership with the SPRF.

GENERAL ASSEMBLY OF THE CHURCH OF SCOTLAND 2O17: $\$ 9.5$

In talking of "rehabilitating" pilgrimage, the intention was to present ways of approaching and appreciating pilgrimage that could fit into the Reformed tradition, understanding reconnections with the landscape, Christian heritage, and narrative culture as valuable spiritual and social tools. One Church of Scotland minister and advocate of pilgrimage told me, "Story sharing in companionship on the road is the real miracle of pilgrimage, not relics and holy wells." ${ }^{17}$ The opportunities afforded by pilgrimage for meaningful experiences for those within and beyond the church walls are seen as enormous. The previously mentioned minister recalled the impact a stay on Iona had on him as a teenager; from that he realized that "one deep, rich, powerfully spiritual experience" could be infinitely more effective than attending Sunday School week after week. ${ }^{18}$

Together We Walk (Church of Scotland 2014a) reflected on not simply Scotland's European links, but how they had been forged in relation to sharing ideas and significant reforms:

Huguenots, Waldensians, Bohemians, Moravians, Silesians, Slovaks, Hungarians, Flemish, Polish, Germans, Scandinavians, Swiss, English,

17 Personal communication, April 2020.

18 Personal communication, April 2020. 
Scots, and more, walked together, thought, discussed, prayed, and acted for a change in ecclesiastical systems, as together they reimagined a different future: Ecclesia reformata semper reformanda, a church always in need of being reformed, and traditions of being reinterpreted, for each new age.

CHURCH OF SCOTLAND 2O14a: 6

For numerous people within the Church of Scotland, the need for change and the opportunity to reinterpret tradition have been presented through the new understandings and manifestations of pilgrimage in Scotland. For the Church of Scotland this "rehabilitation" of pilgrimage may be strategic, it may be unmistakably Protestant in tone, and by no means would everyone within the Church of Scotland be happy with it, but it is nevertheless enormously significant as a measure and marker of the extent to which pilgrimage - albeit a rather particular understanding of it, influenced both by the Camino and particularly Scottish concerns - is becoming normalized and operationalized in a previously hostile environment.

While the "rehabilitation" of pilgrimage in the Church of Scotland is highly significant, as demonstrated already in the work and reports of ACTS and SPRF, it is not only the Church of Scotland that is appreciating the appeal of pilgrimage. Unlike other parts of Northern Europe, for example Norway, pilgrimage initiatives have remained largely locally based, and the national church neither dominates nor oversees pilgrimage developments. Through SPRF, ground level, broad coalitions work in partnership to address a variety of agendas.

One of the most interesting and professionally executed new paths is the 64-mile Fife Pilgrim Way (FPW), officially launched in July 2019. The route has two starting points, Culross Abbey and North Queensferry, merges at Dunfermline Abbey, and ends in St. Andrews (see Figure 3).The route specifically involves the two formerly high-status medieval Catholic pilgrimage sites related to St. Andrew and St. Margaret that were destroyed in the aftermath of the Reformation, and which remain contested. It also passes through areas connected with the intra-Protestant violence of the 17th century, at the time of the anti-Episcopalian, pro-Presbyterian Covenanters. A leaflet produced to publicize the FPW invites people to 


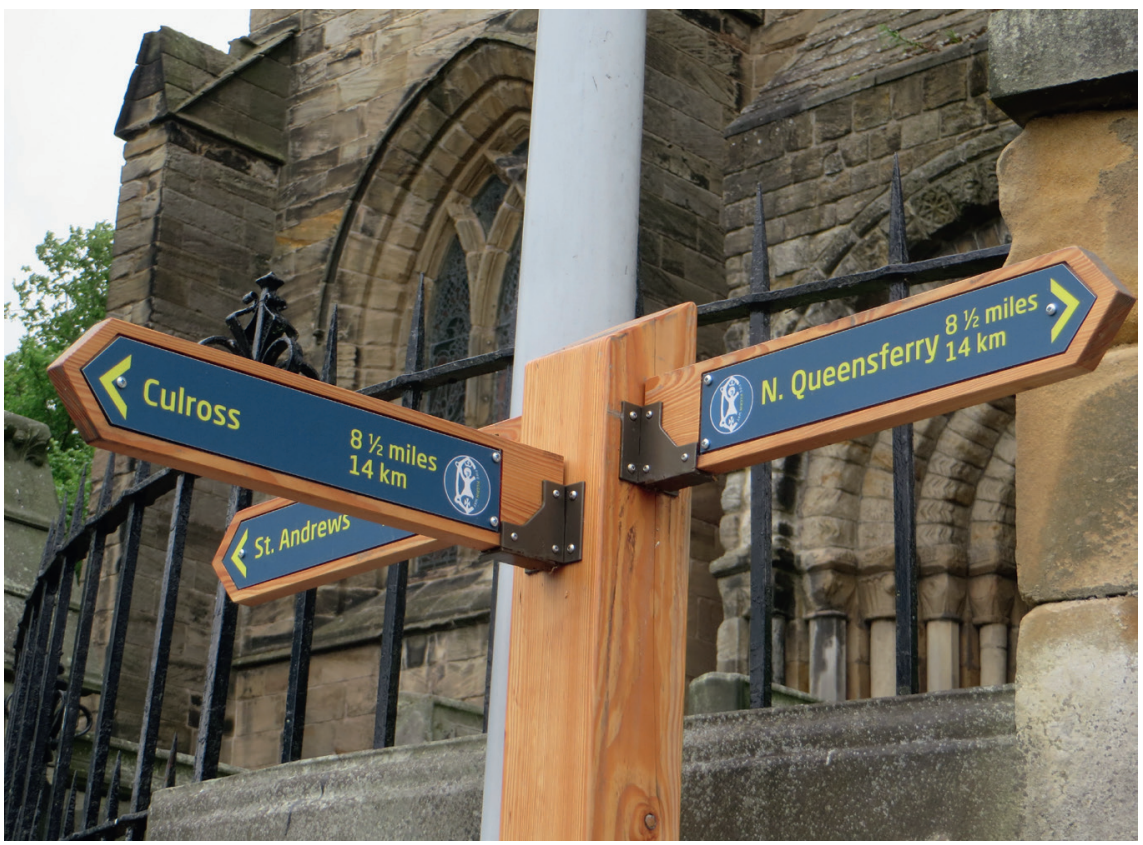

FIgURE 3 Fife Pilgrim Way waymarker, Dunfermline PHOTO: MARION BOWMAN

Get away from it all and enjoy the fresh air and exercise by becoming a modern day pilgrim. Undertake an inspiring journey by walking the ancient pathways, visit the medieval sites along the route and uncover Fife's forgotten pilgrim stories. As in medieval times, you will find a choice of shelter and hospitality, whilst enjoying the kindness of strangers you meet along the way.

FIFE PILGRIM WAY, n.d.

However, as Bradley (2019) reveals, the FPW "is much more than an exercise in historical reconstruction" and "does not follow the route taken by most medieval pilgrims":

The modern pilgrim way has been deliberately routed through old mining and industrial areas of West Fife and the new town of Glenrothes. This is partly in the hope of bringing economic and other benefits to places which have experienced decline and do not see many visitors, or 
tourists, as has happened in Galicia in Spain, the site of Europe's most famous pilgrim way, the Camino de Santiago.

Various agendas and agencies informing new Scottish pilgrimage have coalesced to produce the fully waymarked new pilgrim route, developed over the course of seven years, with eight "gateways" (accessible by public transport) along the route to make it amenable to being walked in day segments in addition to use as a long-distance path. Roger Pickering, of Forth Pilgrim, a Dunfermline based social enterprise company delivering pilgrimage-focused educational experiences for schoolchildren, was involved from the start. ${ }^{19}$ Having moved to Dunfermline, he "saw a similarity between the 'pilgrim corridor' St. Andrews to Durham \& the Camino d' Santiago" though "in Spain it was revived as a cultural / economic driver \& in Fife it was a neglected asset."20 Pickering still hopes the F PW will link with Durham eventually.

The first meeting of the Fife Pilgrim Way Network took place in July 2012, bringing together diverse local interested parties. The development of the FPW eventually involved a number of partners and funders, including the SPRF, Fife Council, Fife Tourism Trust, Fife Cultural Trust, Fife Environment Trust, Central Scotland Green Network, Scottish Natural Heritage, Historic Environment Scotland, The European Agricultural Fund for Rural Development, and the Scottish Parliament; it also received funding from the National Lottery Heritage Fund Scotland. A project manager and community and business engagement officer were appointed in 2017, with the Fife Coast and Countryside Trust (FCCT, an independent environmental charity that manages a number of sites and paths, including the 117-mile Fife Coastal Path) acting as the lead body for developing and maintaining the FPW.

For the SPRF and others involved in the project, the spiritual, community, and economic benefits afforded by pilgrimage were seen to be considerable, along with the opportunities "heritagization" might present both for visitors and those living along the way, especially in those places that had experienced decline (such as former mining areas) and for whom being "put on the map" and having the chance to tell their story was significant. The multifarious ways in which heritage is invoked and employed in relation to the FPW are seen in relation to a number of the project aims, which were to:

\footnotetext{
19 In 1996 Pickering led a 2200-mile Reconciliation Walk on the 9ooth anniversary of the First Crusade from Cologne to Istanbul, apologising for this "armed pilgrimage."

Personal email communication, April 2016.
} 
Enable and encourage all people, visitors and residents alike, to enjoy, appreciate, understand and learn about the heritage value of the area as a place of significance in terms of the importance to mediaeval pilgrimage and beyond ...

Engage and enrich communities located on the route by increasing access, awareness and enjoyment of the built and natural heritage ...

Identify, conserve and where possible restore key historic features and highlight traditional routes that reconnect people with the cultural heritage of the region ...

Involve communities in turning their assets into experiences through heritage focused collaborations.

ROBINSON 2O19: 1-2

As one aim was "involving people in maintaining and learning about their heritage" (Robinson 2019: 1), throughout the development of FPW there was considerable emphasis on working with local groups and volunteers, in activities such as an archaeological dig, involving local trainees and apprentices in some of the physical work on paths and walls, and organizing walks, talks, community events, and educational activities with and for people in the "gateway" communities. One innovative vehicle (literally) for engaging local people and publicizing the FPW has been the MAC bus, Fife Cultural Trust's mobile museum with its current exhibition "The Pilgrims Express." ${ }^{21}$ Designed to promote the new route and encourage people to use it, "The Pilgrims Express" features information about the route and medieval pilgrimage, and has a number of hands-on activities for children such as dressing-up and making pilgrim badges. An audio booth in the bus allows people to record their own thoughts and impressions about walking the FPW, in anticipation of the route inspiring new pilgrim stories.

Local buy-in, energy, enthusiasm, and initiative are seen as vital for the FPW to flourish and fulfill the various spiritual, educational, community-building, environmental, health, and economic aspirations for it. A business partnership scheme offers the opportunity for businesses (such as cafes, accommodation providers, and shops) to appear on FPW publicity. SPRF in collaboration with ACTS have produced a leaflet inviting local congregations to become actively involved in FPW, stating that all ACTS member churches "are committed to

21 In the period April-November 2019, MAC bus visited 20 care homes, 12 educational establishments, 22 community venues or groups and 4 galas/festivals; of 3934 visitors, 848 were children (16 years and under) in organized school or youth groups. Personal communication from Janice Crane, curator, 27 March 2020. 
rehabilitating and promoting pilgrimage activities in the everyday life and work of local churches" (Scottish Pilgrim Routes Forum 2019b). They were involved in planning three ecumenical pilgrimage events in 2018 and early 2019: a 14-mile pilgrimage walk from Ceres to St. Andrews, organized by the Scottish Episcopal Church; a 5-mile family pilgrimage walk; and a "Plainsong \& Pilgrimage" 8-mile walk between Culross and Dunfermline Abbey Church with two short public workshops in medieval plainsong chants at the start and finish of the walk.

The F PW was officially launched in July 2019. There are currently no figures for its use, and the first-year numbers will inevitably be negatively influenced by Covid-19. However, according to FWP personnel within FCCT, there seems to be good anecdotal evidence from the summer of 2019 that it has been very popular with local people using it on a regular basis (in much the same way as the Fife Coastal Path is a valued local amenity), with church groups, charity walkers, and diverse visitors from outside the area contributing positively to the local economy. A second edition of the FPW trail maps (paid for walking maps) became necessary after the first run of 1000 sold out.

As with other "restored" and new pilgrim routes devised in areas where pilgrim culture has had to be (re)developed, the creation of a range of material culture artifacts has been important for developing the identity of the FPW. The logo (Figure 4), which appears on the badges, waymarkers, maps, guides, promotional material, FPW passports, t-shirts, wax sandwich wrappers, dogbandanas, hats, and other FPW related and approved items (sold online and

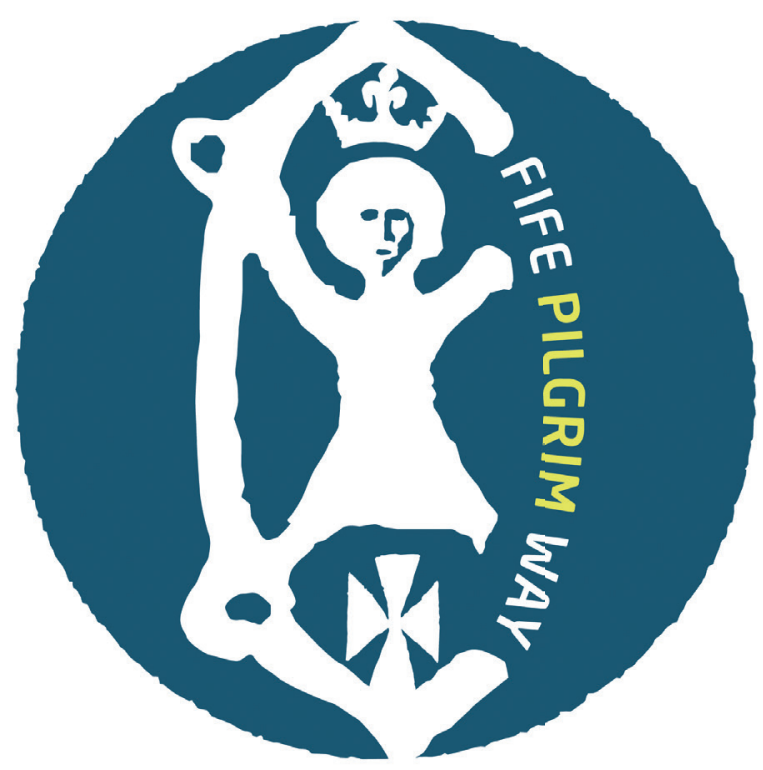

FIGURE 4

Fife Pilgrim Way logo COPYRIGHT FIFE COAST AND COUNTRYSIDE TRUST 


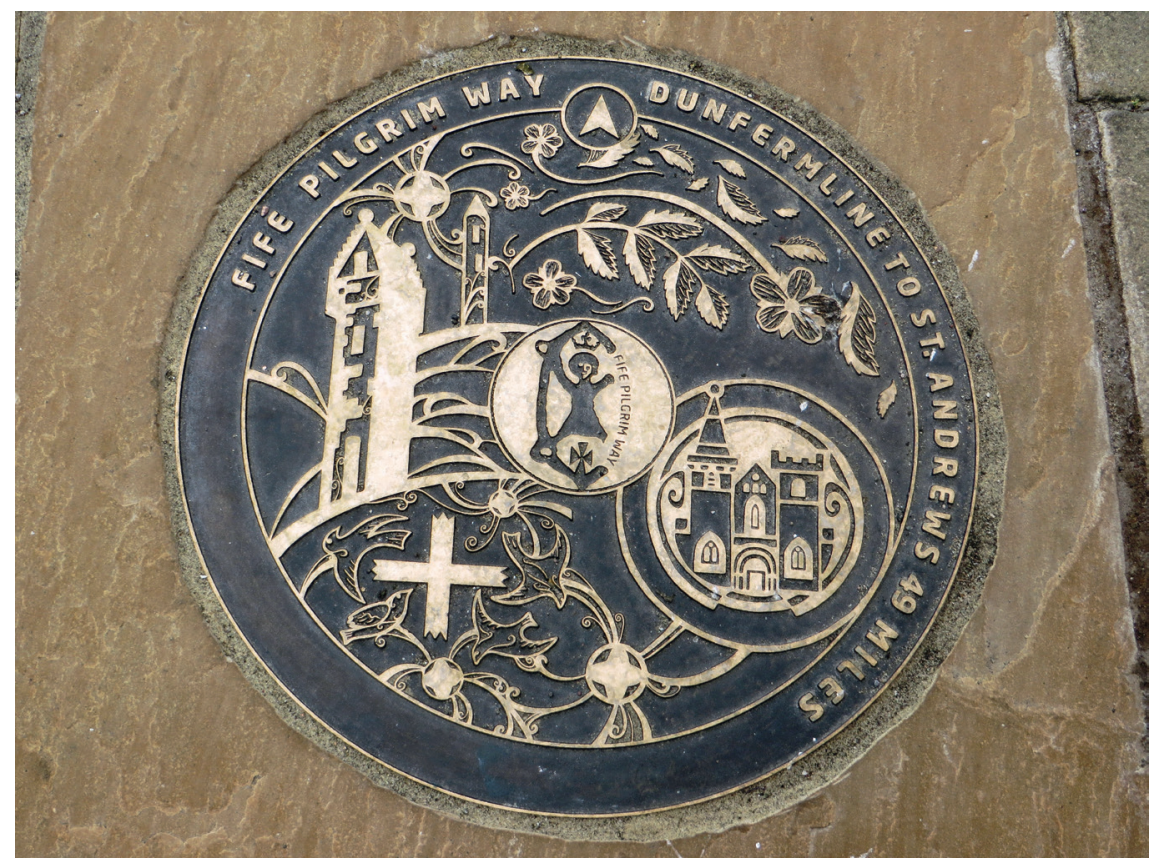

FIGURE 5 "Pilgrim Footprint" set into pavement in Dunfermline PHOTO: MARION BOWMAN

at some venues along the F PW) is based on a 15th-century lead pilgrim badge, depicting St. Andrew. For the logo, above the figure a crown representing Fife's royal connections, and below a carved cross from Markinch Parish Church have been added. The gap in the border of the original badge allows for the insertion of "Fife Pilgrim Way" (see Bradley 2019: 15).

In addition to the branded waymarkers (Figure 3), there are cast metal "Pilgrim Footprints" (Figure 5) set into the ground at "sites of pilgrim significance" along the route, incorporating a design appropriate to each place, based on discussion with local community and heritage groups (Differentia 2019); these designs appear as the preprinted "stamps" on the FPW passport. Based on community generated information, "Gateway Arches" have been designed for each gateway location, featuring the colorful stylized map produced for FPW by artist Jennifer Proudfoot as well as local information relevant to the Way. A vote on the F PW Facebook page decided the quotes to be etched on four rural rest point boulders placed along the Way. Drawn from an eclectic range of sources, quotes chosen included "I have time to ponder, imagine, daydream" by Kevin A. Codd, an American Roman Catholic priest, whose book To the Field of Stars recounts his pilgrimage to Santiago de Compostela, and "He is tuise faine 
that sitis on a stane" (He is well pleased who sits on a stone), from a collection of proverbs in Scots language published by James Carmichaell (1543-1628), an anti-Episcopalian Presbyterian minister. In addition to such specific material cultural additions to the FPW landscape, Bradley gives examples of local communities creating points of interest along the Way. In Kinglassie, volunteers have cleaned and opened up an old well, Finglassin's Well, "which may perhaps have been used by medieval pilgrims en route to Andrews ... in the hope that it will attract modern pilgrims" (Bradley 2019: 152). Meanwhile, in the "rather soulless" new town of Glenrothes (established 1951), St. Columba's Church of Scotland parish church has sponsored a labyrinth at Riverside Park, adjacent to the FPW. This is all a long way from the natural and built heritage encountered by medieval pilgrims, but efforts are being made to restore and re-story a meaningful framework within which a broad range of people can experience "new" pilgrimage with heritagized elements from Fife's pilgrim past, heavily influenced by Caminoization.

One of the most significant productions in relation to the FPW is Ian Bradley's book The Fife Pilgrim Way (2019). It functions in many ways, not only as a source of information about the route, but as a manifesto for new pilgrimage generally. Bradley outlines the differences between medieval and modern pilgrims and the text is interspersed with accounts of experiences from the many pilgrimage activities in which he has participated (including the St. Olav Way), as the benefits of pilgrimage today are extolled. The rationale behind the creation of the FPW is outlined, mentioning people who had pioneered it, with examples of Roman Catholic, ecumenical, and interfaith initiatives around pilgrimage. Bradley claims the book is not a guidebook, although it does contain considerable detail and narratives about the places through which the route passes and people connected with it historically; rather, he states, it "aims to set the Fife Pilgrim Way in its historical and spiritual context" (2019: 28). It gives accounts of complicated, significant, and uncomfortable religious events in Scotland, too often glossed over or narrated over-simplistically at a popular level, with sections on both the Reformation and the intra-Protestant Presbyterian-Episcopalian disputes of the Covenanting period.

As we see elsewhere in this issue of Numen (Johannsen and Ohrvik 2020), guidebooks can be influential devices for framing the expectations and focusing the attention of walkers; Bradley's The Fife Pilgrim Way does that and more. For scholars of contemporary Northern European pilgrimage, it provides valuable insights into the many ways in which "new" pilgrimage creatively draws upon heritagization and Caminoization to create a broadly encompassing, socially, spiritually, and nationally relevant rehabilitation of pilgrimage in 21stcentury Scotland. 
Pilgrimage in Scotland can be seen in relation to the broader contemporary movement in some areas of previously Protestant Northern Europe, where people in countries and denominational traditions that firmly rejected the theological underpinnings, material culture, and praxis of pilgrimage in the past, now appear to "believe in" pilgrimage as a meta-religious phenomenon. The multivalency of pilgrimage has enabled "sequential re-invention of its appeal and relevance across disparate contexts" (Dyas and Jenkins 2020: 7).

Scotland is once again being crisscrossed with pilgrimages, pilgrim routes, and self-identified pilgrims. Disparate religious and socioeconomic trends, agents, individuals, and groups have coalesced in traditionally Calvinist Protestant Scotland to produce a new appetite for "rehabilitated" pilgrimage, which is now being promoted as a vehicle for community building and regeneration, seen as capable of bringing people into new relationship with the landscape, built and intangible heritage, the contested past, and each other. The roots of the Caminoization and heritagization in the flourishing contemporary pilgrim culture lie in Scotland's complex identity politics, including Celticism, sectarianism, pro-European sentiments, and pragmatic theological reassessment of its fragmented pilgrimage past.

Eriksen makes the point that "anything can become heritage as long as somebody declares him- or herself its heir," but cautions that "the valorization is ... fashioned by present values and issues and profoundly shaped by the present context" (Eriksen 2014: 149). In relation to pilgrimage, people seemingly want to become heirs to a pilgrim past, real or imagined, which the heritagization of religion appears to make possible. However, while pilgrimage is being rediscovered and reframed, and people are feeling elective affinity with a rich European medieval cultural heritage, what is happening in Scotland is not a revival of the pre-Reformation tradition. Much is made of walking in the footsteps of pilgrims past, but the goals and underlying assumptions are rather different. As I have demonstrated here, the rehabilitated pilgrimage and the heritagization of religion being promoted and embraced is a distinctively Scottish, Protestant-influenced development.

It is important to remember that despite the Reformation and Protestant state church dominance in Scotland, Roman Catholicism and its pilgrimage tradition did not simply disappear. With the numerical growth of Roman Catholicism in Scotland due to Irish immigration in the 19th century, for example, and the growing confidence and public presence of the church in the 2oth century, there was an enthusiastic Catholic revival of pre-Reformation Scottish shrines and pilgrimages (Proctor and Gillick 2019). Although the 
original shrine of St. Margaret in Dunfermline Abbey was destroyed, the Roman Catholic St. Margaret's Memorial Church, now housing a relic of St. Margaret, opened in 1896. The first modern Catholic St. Margaret pilgrimage took place in Dunfermline in 1899, and modern annual pilgrimages include a procession to the remains of St. Margaret's shrine. Despite the material ravages of the Reformation, then, in Dunfermline there are Catholics who see themselves continuing "authentic" Catholic tradition in relation to pilgrimage, St. Margaret, her relics, and her shrine. Similarly, the Confraternity of St. Ninian, founded in 2017, is a lay association promoting "the reconversion of Scotland to the Catholic Faith through pilgrimages," focusing on the annual Two Shrines Pilgrimage, a three-day walking pilgrimage from the national shrine of St. Andrew (housed in the 19th-century St. Mary's Catholic Cathedral, Edinburgh, which contains two relics of St. Andrew) to the site of the medieval shrine (destroyed in 1559) in the ruined St. Andrews Cathedral (see Confraternity of St. Ninian, n.d.). Although there are now significant interfaith initiatives in Scotland in relation to new pilgrim ways, a Catholic Trustee on SPRF, and active participation by Catholic representatives in ACTS, there remain nevertheless parallel views and praxis in relation to Scotland's pilgrim past and present, despite the inclusive rhetoric and spirit of the 21st-century revival.

The broad appeal of pilgrimage and new pilgrim routes to a wide range of people in Scotland is beyond dispute. The Fife Pilgrim Way, for example, has been described as "an open-air spiritual resource open to all, whether faith believers or not."22 However, here I have highlighted how the "rehabilitation" of pilgrimage has been perceived and promoted primarily in relation to Scottish Christianity, both institutional and vernacular. That pilgrim routes might be seen by some as new Christian mission fields is beyond dispute, but what emerges from this study is the emphasis among a variety of significant actors on what pilgrimage might do for and among Christians, as well as for and in broader civil society, in terms of economic regeneration, community cohesion, enhanced health, increased environmental awareness, and sustainability. In the desire to find new purposes for church buildings and dwindling congregations, for example, people are being urged not just to see themselves as pilgrim heirs, but as the heirs of those providing pilgrim services in the past.

That "the Protestant Churches are leading the resurgence of Christian pilgrimage across northern Europe" (Cooke 2020), a statement which not so long ago would have seemed oxymoronic, highlights the extent to which ideas, like 
people, are on the move. Keeping track of such movements is important for the study of lived religion if we are to understand the enormous range of what people are envisaging, doing, and experiencing in the name of pilgrimage today.

\section{Acknowledgments}

I would like to thank Nick Cooke (Secretary, Scottish Pilgrim Routes Forum), John Henderson (Walking Support) and Ed Heather-Hayes (Head of Development at Fife Coast and Countryside Trust) for their time, cooperation, and many stimulating and informative conversations in recent years.

\section{References}

ACTS Scottish Churches Rural Group (SCRG). 2018. Hope in the Rural Church-Reflections on the Scottish Church Census Report. URL: http://www.acts-scotland.org/images /downloads/rural_group/SCRG_HopeRuralChurch_Report2018.pdf (accessed 17 April 2020).

ARC (Alliance of Religion and Conservation).n.d. "Projects: Green Pilgrimage Network." URL: http://www.arcworld.org/projects.asp?projectID=549 (accessed 7 April 2020). Bhattacharjee, Krittika. 2018. "Once Upon a Place: The Construction of Specialness by Visitors to Iona." Ph.D. dissertation, University of Edinburgh.

Bowman, Marion. 1993. "Reinventing the Celts." Religion 23(1): 47-56.

Bowman, Marion. 2000. "Contemporary Celtic Spirituality." In A. Hale and P. Payton (eds.), New Directions in Celtic Studies, Exeter: Exeter University Press, 69-91.

Bowman, Marion, and Tiina Sepp. 2019. "Caminoisation and Cathedrals: Replication, the Heritagization of Religion, and the Spiritualisation of Heritage." Religion 49(1): 74-98.

Bowman, Marion, Dirk Johannsen, and Ane Ohrvik. 2020. "Reframing Pilgrimage in Northern Europe: Introduction to the Special Issue." Numen 67 (5-6): 439-452.

Bradley, Ian. 1999. Celtic Christianity: Making Myths and Chasing Dreams. Edinburgh: Edinburgh University Press.

Bradley, Ian. 2019. The Fife Pilgrim Way: In the Footsteps of Monks, Miners and Martyrs. Edinburgh: Birlinn.

Brierley, Peter. 2017. Growth Amidst Decline: What the 2016 Scottish Church Census Reveals. Tonbridge: ADBC Publishers.

Butler, Jenny. 2020. "Contemporary Pagan Pilgrimage: Ritual and Re-Storying in the Irish Landscape." Numen 67(5-6): 613-636. 
Castro Fernández, Belén María. 2016. "The Way of Saint James: Memory, Propaganda and Power." In Avril Maddrell, Alan Terry, and Tim Gale (eds.), Sacred Mobilities: Journeys of Belief and Belonging, Abingdon: Routledge, 129-143.

Church of Scotland. 2014a. World Mission Council Report 2014: Together We Walk. URL: https://churchofscotland.org.uk/serve/world-mission/get-involved/reports-andresources/together-we-walk/687-wm-popular-report.pdf (accessed 14 May 2020).

Church of Scotland. 2014b. World Mission Council 2014: Together We Walk - A European Themed Pilgrimage in your Church. URL: https://churchofscotland.org.uk/_data/ assets/pdf_file/ooo7/22399/Together-We-Walk-Church-Pilgrimage.pdf (accessed 14 May 2020).

Colley, Kathryn, and Katherine N. Irvine. 2018. "Investigating Use of the Outdoors across Adult Population Groups in Scotland." Social, Economic \& Geographical Sciences Group, The James Hutton Institute. URL: https://www.hutton.ac.uk/sites/ default/files/files/Fullreport-use-of-the-outdoors.pdf (accessed 14 May 2020).

Coleman, Simon, and Marion Bowman. 2019. "Religion in Cathedrals: Pilgrimage, Heritage, Adjacency, and the Politics of Replication in Northern Europe." Religion 49(1): $1-23$.

Confraternity of St Ninian. n.d. "About." URL: https://confraternity-of-st-ninian.com/ about/ (accessed 17 April 2020).

Cooke, Nick. 2012. "Pilgrimage Routes across Scotland: New Developments." Open House, April/May, 15. URL: http://www.openhousescotland.co.uk/PDFs/OH_2O12 _04_April_May_low.pdf (accessed 14 May 2020).

Cooke, Nick. 2020. Pilger-Messe at St Jacobi Hauptkirche, Hamburg: 21-23, February 2020. Scottish Pilgrim Routes Forum.

Cusack, Carol M. 2013. "History, Authenticity, and Tourism: Encountering the Medieval While Walking Saint Cuthbert's Way." In Alex Norman (ed.), Journeys and Destinations: Studies in Travel, Identity and Meaning, Newcastle upon Tyne: Cambridge Scholars Publishing, 1-21.

Differentia. 2019. Fife Pilgrim Way Gateway Signs. Differentia Interpretation and Design for Outdoor Spaces. URL: https://www.differentia.co.uk/news/2019/8/3o/ fife-pilgrim-way (accessed 17 April 2020).

Dyas, D. and John Jenkins. 2020. “Introduction." In Dee Dyas and John Jenkins (eds.), Pilgrimage and England's Cathedrals: Past, Present, and Future, London: Palgrave MacMillan, 1-26.

Eco-Congregation Scotland. n.d. Vision and Values. URL: vhttps://www.ecocongrega tionscotland.org/about-us/about/ (accessed 17 April 2020).

Eriksen, Anne. 2014. From Antiquities to Heritage: Transformations of Cultural Memory. New York: Berghahn. 
Fife Pilgrim Way.n.d. “The Fife Pilgrim Way: Discover Scotland's Pilgrim Kingdom." Leaflet. URL: https://dissuo7opg2v9i.cloudfront.net/pex/fcct/2019/o7/02164735/Fife-Pilgrim -Way.pdf (accessed 14 May 2020).

Frazer, Richard. 2019. Travels with a Stick: A Pilgrim's Journey to Santiago de Compostela. Edinburgh: Birlinn.

Frey, Nancy Louise. 1998. Pilgrim Stories. 1st ed. Berkeley: University of California Press. Gemzöe, Lena. 2012. "Big, Strong and Happy: Reimagining Femininity on the Way to Compostela." In Willy Jansen and Catrien Notermans (eds.), Gender, Nation and Religion in European Pilgrimage, Farnham: Ashgate, 37-53.

General Assembly of the Church of Scotland. 2001. The Report of the Special Commission anent Review and Reform: A Church without Walls. URL: https://churchofscotland .org.uk/_data/assets/pdf_file/ooo6/11787/CWW_REPORT_for_website_2Nov2O12 .pdf (accessed 14 May 2020).

General Assembly of the Church of Scotland. 2017 Word of Life. Edinburgh: Church of Scotland. URL: http://www.churchofscotland.org.uk/_data/assets/pdf_file/0005/ 39533/Blue_Book_2017.pdf (accessed 14 May 2020).

Leerssen, Joep. 1996. “Celticism." In T. Brown (ed.), Celticism (Amsterdam Studies on Cultural Identity, 8), Amsterdam: Studia Imagologica, 1-16.

Maddrell, Avril, and Richard Scriven. 2016. "Celtic Pilgrimage, Past and Present: From Historical Geography to Contemporary Embodied Practices." Social \& Cultural Geography 17(2): 300-321.

Margry, Peter J. 2008 “Secular Pilgrimage: A Contradiction in Terms?" In Peter J. Margry (ed.), Shrines and Pilgrimage in the Modern World: New Itineraries into the Sacred, Amsterdam: Amsterdam University Press, 13-46.

Meek, D. E. 200o. The Quest for Celtic Christianity. Edinburgh: Handsel Press.

Mikaelsson, Lisbeth. 2005. "Locality and Myth: The Resacralization of Selja and the Cult of St. Sunniva." Numen 52(2): 191-225.

Mikaelsson, Lisbeth. 2019. "Nidaros Cathedral: A Recreated Pilgrim Church." Religion 49(1): 99-119.

Mikaelsson, Lisbeth, and Torunn Selberg. 2020. "Caminoization at Sea: The Fjord Pilgrim Route in Norway." Numen 67 $\left(5^{-6)}\right.$ : 537-556.

Power, Rosemary. 2006. "A Place of Community: 'Celtic' Iona and Institutional Religion." Folklore $117(1)$ : 33-53.

Proctor, Robert, and Ambrose Gillick. 2019. "Pilgrimage and Visual Genre: The Architecture of Twentieth-Century Roman Catholic Pilgrimage in Scotland." Material Religion 15(4): 456-487.

Reader, Ian. 2014. Pilgrimage in the Marketplace. New York: Routledge.

Robinson, Rob. 2019. Fife Pilgrim Way Project Evaluation Final Report. Edinburgh: Heritage Consulting. 
Scotland's Great Trails. 2020. Homepage. URL: https://www.scotlandsgreattrails.com/ (accessed 26 May 2020).

Scottish Natural Heritage. 2018. Scotland's Networks of Paths and Trails: Key Research Findings. URL: https:/www.nature.scot/sites/default/files/2018-o9/Research\%2O Consolidation\%2oReport.pdf (accessed 14 May 2020).

Scottish Pilgrim Routes Forum. n.d. Homepage. URL: https://www.sprf.org.uk/ (accessed 1 April 2020).

Scottish Pilgrim Routes Forum. 2019a. "Reviving Scotland's Pilgrimage Heritage." Leaflet.

Scottish Pilgrim Routes Forum. 2019b. "Opportunities for Local Churches." Leaflet.

Sepp, Tiina, and Atko Remmel. 2020. "The Pilgrimage Landscape in Contemporary Estonia: New Routes, Narratives and Re-Christianization." Numen 67(5-6): 586-612.

Shaw, Ron. 2016. 2oth Anniversary Edition St Cuthbert's Way Melrose to Lindisfarne Official Trail Guide. Edinburgh: Birlinn, 2016.

Smith, Laurajane. 2006. Uses of Heritage. London: Routledge.

St. Cuthbert's Way. n.d. Homepage. URL: https://www.stcuthbertsway.info (accessed 1 April 2020).

Turpie, Tom. 2016. Fife Pilgrim Way Report Detailing Historical References to Pilgrimage and the Cult of the Saints in Fife. Report. URL: https://fifecoastandcountrysidetrust. co.uk/plan-your-trip/resources/fife-pilgrim-way/ (accessed 29 March 2020).

Walking Support 2010. Pilgrimage Ways and Tours. URL: http://www.walkingsupport .co.uk/pilgrimage.html (accessed 1 April 2020).

Yeoman, Peter. 1999. Pilgrimage in Medieval Scotland. London: B.T.Batsford/Historic Scotland. 